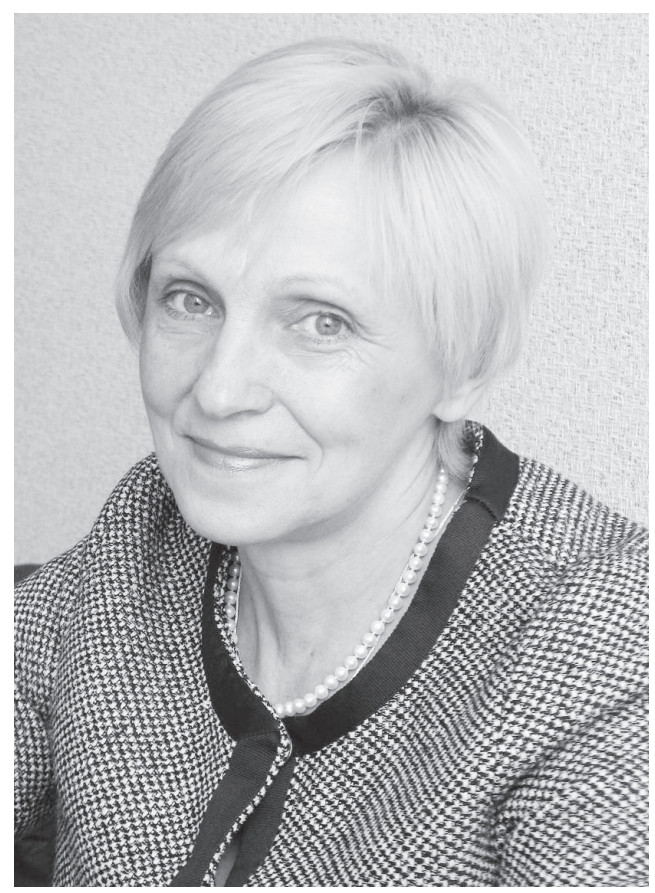

УДК : 351.82:659.1]-027.21(477)

DOI: https://doi.org/10.32689/2617-

2224-2019-18-3-402-411

Сердечна Людмила Василівна,

кандидат наук з державного управління, докторант, Національна академія державного управління при Президентові України, 03057, м. Киів, вул. Антона Цедіка, 20, тел.: +38 (095) 55178 85, e-mail: lvserdechna@gmail.com

ORCID: 0000-0002-4311-3596

Сердечная Людмила Васильевна, кандидат наук по государственному управлению, докторант, Национальная академия государственного управления при Президенте Украины, 03057, г. Киев, ул. Антона Цедика, 20, тел.: +38 (095) 55178 85,e-mail: loserdechna@gmail.com

ORCID: 0000-0002-4311-3596

Serdechna Liudmyla Vasyliona,

Candidate of sciences in public administration, doctoral candidate, National Academy for Public Administration under the President of Ukraine, 03057, Kyiv, Str. Antona Tsedika, 20, tel.: +38 (095) 55178 85, e-mail: lvserdechna@gmail.com

ORCID: 0000-0002-4311-3596

\title{
РЕГУЛЮВАННЯ СФЕРИ РЕКЛАМИ В КОНТЕКСТІ СТАЛОГО РОЗВИТКУ УКРАЇНИ (АРХЕТИПНИЙ ПІДХІД)
}

Анотація. Розглядаються актуальні питання теорії і практики регулювання у процесі формування та реалізації державної політики у сфері реклами, зокрема, методологічні проблеми застосування архетипного підходу для аналізу регулювання реклами в контексті сталого розвитку України. Рекламна діяльність в сучасних умовах впливає на формування ціннісних орієнтацій суспільства і є однією з причин загострення соціальних суперечностей. Багатовекторність реклами і масовий характер зумовлюють проблеми її функціонування, зокрема таку, як вплив на раціональність споживання в сучасному суспільстві. Одним з основних завдань реклами є стимулювання споживання, а отже, вирішення завдання збалансованого споживання, що визначене Стратегією сталого розвитку України до 2030 р., створює суперечність. Вирішення проблеми вимагає трансформації концептуальних основ регулювання рекламної сфери. Обгрунтовано необхідність ви- 
роблення парадигми регулювання реклами на основі ціннісних установок, на яких грунтується концепція сталого розвитку i, зокрема, збалансованого споживання. Певні ціннісні установки (архетипи), що зумовлюють розвиток регулювання, відповідно мають вплив і на рівень корпоративної соціальної відповідальності рекламного бізнесу і сприяють досягненню гармонізації відносин рекламного бізнесу, суспільства і держави. Обгрунтовано висновок, що питання ціннісних установок у регулюванні реклами з позицій завдань Стратегії сталого розвитку щодо збалансованого споживання не має ставитися як вибір альтернативи. Оптимальне співвідношення матеріальних інтересів бізнесу й нематеріальних цінностей суспільства в регулюванні рекламної сфери залежить від співвідношення ціннісно-смислових архетипів, коли суб’єкти рекламної діяльності мають дієву мотивацію щодо соціальної відповідальності, яка доповнює, а не виключає корпоративні інтереси.

Ключові слова: реклама, архетипи, Стратегія сталого розвитку, регулювання в рекламній сфері.

\section{РЕГУЛИРОВАНИЕ СФЕРЫ РЕКЛАМЫ В КОНТЕКСТЕ УСТОЙЧИВОГО РАЗВИТИЯ УКРАИНЫ (АРХЕТИПНЫЙ ПОДХОД)}

Аннотация. Рассматриваются актуальные вопросы теории и практики регулирования в процессе формирования и реализации государственной политики в сфере рекламы, в частности, методологические проблемы применения архетипного подхода для анализа регулирования рекламы в контексте устойчивого развития Украины. Реклама в современных условиях влияет на формирование ценностных ориентаций общества и является одной из причин обострения социальных противоречий. Массовый характер рекламы обусловливает проблемы ее функционирования, в частности, такую как влияние на рациональность потребления в современном обществе. Одной из основных задач рекламы является стимулирование потребления, а следовательно, решение задачи сбалансированного потребления, поставленной в Стратегии устойчивого развития Украины до 2030 г., создает противоречие. Решение проблемы требует трансформации концептуальных основ регулирования рекламной сферы. Обоснована необходимость выработки парадигмы регулирования рекламы на основе ценностных установок, на которых основывается концепция устойчивого развития и в частности сбалансированного потребления. Определенные ценностные установки (архетипы), обусловливающие развитие регулирования, соответственно имеют влияние на уровень корпоративной социальной ответственности рекламного бизнеса и способствуют достижению гармонизации отношений рекламного бизнеса, общества и государства. Обоснован вывод, что вопрос ценностных установок в регулировании рекламы с позиции задач Стратегии устойчивого развития по сбалансированному потреблению не должен ставиться как выбор альтернативы. Оптимальное соотношение материальных интересов бизнеса 
и нематериальных ценностей общества в регулировании рекламной сферы зависит от соотношения ценностно-смысловых архетипов, когда субъекты рекламной деятельности имеют действенную мотивацию социальной ответственности, которая дополняет, а не исключает корпоративные интересы.

Ключевые слова: реклама, архетипы, Стратегия устойчивого развития, регулирование в рекламной сфере.

\section{REGULATION OF THE ADVERTISING IN THE CONTEXT OF THE SUSTAINABLE DEVELOPMENT OF UKRAINE (ARCHETYPICAL APPROACH)}

Abstract. The article covers the actual questions of the theory and practice of regulation of the advertising in the process of formation and implementation of state policy in the field of advertising. In particular, the methodological problems of using the archetypical approach for analyzing the regulation of advertising in the context of the sustainable development of Ukraine. Advertising activity in modern conditions affects the formation of key value orientations of society and is one of the causes of aggravation of social contradictions. One of the main objectives of advertising is to stimulate consumption, and therefore the solution of the problem of balanced consumption, as defined by the Strategy of Ukraine's Sustainable Development till 2030, creates a contradiction. Solving the problem requires the transformation of the conceptual framework of regulation of advertising sphere. The author advocates the necessity of developing a paradigm of regulation of advertising on the basis of value systems based on the concept of sustainable development and, in particular, on balanced consumption. Certain value systems (archetypes), which predetermine the development of regulation, respectively, have an impact on the level of corporate social responsibility of the advertising business and contribute to the harmonization of relations advertising business, society and the state. It is substantiated in the article that the question of value systems in regulation of the advertising from the standpoint of tasks of the Strategy of Sustainable Development in relation to balanced consumption should not be considered as a choice of alternative. The optimal ratio of the material interests of the business and the intangible values of society in the regulation of the advertising sphere depends on the ratio of value-semantic archetypes, when the subjects of advertising activity have an effective motivation regarding social responsibility, which complements, but does not exclude corporate interests.

Keywords: advertising, archetypes, Sustainable development strategy, regulation of the advertising.

Постановка проблеми. Сучасна реклама відіграє важливу роль не тільки як інструмент ринкової економіки. В Україні за досить короткий період вона сформувалась у розвинену індустрію і потужний соціальний інститут, що впливає на економіку, політику, культуру, стан суспільної 
моралі та інші сфери соціально-економічного життя суспільства. Багатовекторність реклами i i масовий характер відповідно зумовлюють i проблеми ㄲi функціонування, зокрема таку як вплив на раціональність споживання в сучасному суспільстві. Водночас цілі і завдання стратегії сталого розвитку країни, спрямованої на забезпечення економічного зростання, соціальної справедливості та раціонального природокористування, включають у тому числі і необхідність збалансування споживання та виробництва, формування культури споживання. Отже нові підходи до дослідження проблематики регулювання рекламної сфери у контексті сталого розвитку крізь призму архетипіки особливо актуальні для вироблення адекватного розуміння відповідних соціальних явищ і взаємозв’язків, зокрема для осмислення сучасних напрямів ефективного регулювання у сфері реклами.

Аналіз останніх досліджень і публікацій. Питанням вивчення реклами присвячені численні наукові дослідження i публікації. Сучасну рекламу вивчають соціологи й управлінці, психологи та філологи, культурологи й лінгвісти, ㅃï вплив на людину став предметом вивчення навіть в медицині.

Серед наукових досліджень у галузі реклами значну питому вагу мають праці, присвячені проблемам та аспектам рекламної діяльності як різновиду масових комунікацій. Зокрема, питання теорії та практики рекламної комунікації відображено в роботах Т. Амблера, Д. Бернета, В. Фрайбургера, Ф. Котлера, Ж.-Ж. Ламбена, С. Моріарті, Д. Огі- лві, К. Ротцол, Ж. Сегела, Д. Траута, У. Уелса й у наукових дослідженнях українських вчених Г. Почепцова, Є. Ромата та ін.

Аспекти державного управління, в тому числі і у сфері комунікацій та реклами, проблеми ціннісних засад регулювання досліджувались вітчизняними вченими в галузі державного управління, економіки, соціології, права. Зокрема слід відзначити роботи В. Бакуменка, О. Валевського, В. Голубь, Л. Гонюкової, В. Козакова, Г. Почепцова, В. Ребкала, С. Ромата, В. Тертичка та ін.

Новим науковим напрямом у суспільних науках, а також в державному управлінні, стала архетипіка, значною мірою завдяки дослідженням вітчизняних вчених Е. А. Афоніна, О. А. Донченко, О. В. Сушій та ін., праці яких присвячені впливам архетипів на соціальне життя та політику, а також менеджмент та державне управління.

Як теоретичне підгрунтя цього дослідження були також використані наукові праці, де порушуються питання соціальної відповідальності реклами, зокрема Ж. Бодріяйра, Е. Фромма й Ж. Липовецькі.

Метою статті є аналіз регулювання реклами в контексті сталого розвитку України, обгрунтування напрямів збалансування інтересів суспільства і рекламного бізнесу, необхідності забезпечення адекватного регулювання, включаючи державне і громадське на основі архетипного підходу.

Виклад основного матеріалу дослідження. За відносно короткий історичний період реклама в Україні набула не тільки економічного зна- 
чення, а почала відігравати різноманітні і важливі ролі в багатьох сферах соціально-економічного i політичного життя суспільства. У складних умовах трансформаційного періоду в економіці української держави, на тлі скорочення багатьох видів виробництва і навіть зникнення цілих галузей промисловості рекламна індустрія стрімко набирала обертів.

Становлення галузі відбувалось у складні для економіки країни часи. Вітчизняні і зарубіжні науковці, фахівці і політики, експерти Світового банку відзначали, що реформи, які відбулися за чверть століття незалежності у сфері економіки України, мали для ㄲi досить високого промислового потенціалу руйнівні наслідки. Зокрема, за висновком Світового банку, за період 1991-2014 рр. реальний внутрішній валовий продукт (ВВП) встановив світовий рекорд 3 падіння і скоротився на $35 \%$, що стало найгіршим результатом у світі. Вітчизняне виробництво “дістало дна” в 90-ті. Через його щорічне падіння в перші дев’ять років незалежності Україна втратила майже 60 \% ВВП [1].

Але саме в ті роки відбулося становлення i стрімке зростання рекламної галузі, яка практично за кілька років перетворилась із сфери дрібного підприємництва на потужну індустрію і галузь економіки, а також сформувалась у впливовий соціальний інститут. Становлення реклами як економічного явища в новітній історії України припадає саме на 1990-ті роки. До вказаного періоду в тоді ще Українській РСР поняття “реклама” було взагалі відсутне як вид економічної діяльності [2, с. 37].
На кінець 1990-х і початок 2000-х років прийшовся найбільш активний i плідний період формування і розвитку галузі. Наприклад, тільки за п’ять років з 1997 р. по 2002 р. обсяги вітчизняного рекламного ринку, який вже на той час сформувався, зросли в 6 разів і досягли майже 1 млрд дол. США [2, с. 38]. А такий відносний показник ефективності рекламної діяльності як рівень рекламних витрат на 1000 дол. доходів населення у 2001 р. був вищим, ніж аналогічний в США [2, с. 47]. Тобто рекламне "навантаження” на середнього українця в той період було вище у відносному вимірі, ніж навіть на середнього американця. У вартості споживчих товарів і послуг більше 1 \% в середньому становила вартість реклами. Співвідношення рекламних витрат і ВВП на початку 2000-х років перевищувало 2 \%, випереджаючи країни з розвиненою економікою.

Розвиток рекламного ринку i сприятливі умови для рекламного бізнесу зумовили стабільні зростаючі доходи, рекламна галузь сьогодні одна з найприбутковіших в українській економіці. Активне зростання, значною мірою, стало результатом саме сприятливих умов регулювання, включаючи нормативно-правову та інституційну базу. У цей період в Україні сформувалися й успішно співіснували два види регулювання реклами: державне і рекламне саморегулювання. Водночас регулювання такої сфери, що виступає потужним засобом формування цінностей суспільства - питання, яке без перебільшення визначає стан суспільства.

Через рекламу в сучасному суспільному житті виникають деякі 
соціальні та духовні проблеми, рекламна діяльність створює нові виклики, певною мірою поглиблює кризовий стан суспільства. Такий стан не є унікальним тільки для України. Наприклад, на думку американських фахівців з комунікації, на становлення американського способу життя реклама вплинула незгірш, ніж Біблія. Проте в Україні ці зміни відбулися дуже стрімко, що зумовило відставання у розвитку регулювання рекламної сфери від темпів трансформацій в суспільстві, викликаних впливом реклами. А отже дослідження проблеми усунення цього дисбалансу вимагає нових підходів, один з яких базується на вивченні архетипних особливостей як рекламної діяльності, так і формування засад ㄲi ефективного регулювання. При цьому слід зауважити, що сама рекламна індустрія досить активно використовує архетипний підхід для підвищення ефективності реклами.

На думку американських дослідниць архетипів у рекламі Маргарет Марк та Керол С. Пірсон з Сейбрукського університету, “вперше за всю історію людства загальні міфи почали здавати свої позиції, і місце загальних священних переказів зайняла реклама” [3, с. 322]. Застосування архетипів в рекламі - це використання їх позитивного потенціалу з метою отримання прибутку. При цьому існує “потік реклами, яка підкріпляє негативний потенціал архетипу або його прояви на самих низьких рівнях" [3, с. 326].

Результати спеціальних досліджень американської компанії Brand Asset Valuator (BAV), яка здійснювала опитування 120 тисяч респон- дентів в 33 країнах, показали, що за умов, коли бренди компаній чітко відповідають певному архетипу, стабільно збільшується прибуток [3, c. 42]. Це зумовлює ситуацію, коли в сучасному брендінгу і рекламі в цілому інтенсивно експлуатується потенціал архетипів. Дослідження дії архетипної реклами, яка спрямована на дітей і підлітків показало, що в окремих випадках має місце “соціальний тиск” [3, с. 324].

Негативні явища, пов’язані 3 рекламою і в тому числі стимулюванням нераціонального попиту i надмірного споживання, створюють проблеми для суспільства. Так, Всесвітня організація охорони здоров'я (ВОО3) у спеціальному дослідженні проблеми ожиріння в Європі виділила рекламу серед його причин. Йдеться про рекламу шкідливих для здоров’я продуктів, пропаганду нездорового способу життя, стимулювання нераціонального попиту та споживання продовольчих товарів, яка в свою чергу розроблена з урахуванням архетипів. ВООЗ також визнала значну роль реклами продовольчих товарів, спрямовану на дітей, у виникненні та розвитку цієї проблеми серед останніх [4, с. 132164].

Проблема збалансованого споживання в сучасному суспільстві значно глибша i має глобальний характер. На Саміті ООН зі сталого розвитку, що відбувся у вересні 2015 р. у Нью-Йорку, було затверджено нові орієнтири розвитку. Підсумковий документ Саміту “Перетворення нашого світу: порядок денний у сфері сталого розвитку до 2030 року” включає 17 Цілей Ста- 
лого Розвитку та 169 завдань, серед яких збалансоване споживання.

Україна, як і інші країни - члени ООН, приєдналася до глобального процесу забезпечення сталого розвитку. Для встановлення стратегічних рамок національного розвитку у 2017 р. розроблено проект Стратегії сталого розвитку України до 2030 р. (далі Стратегія), а в лютому 2019 р. Верховна Рада України включила до порядку денного Проект Закону про Стратегію сталого розвитку України до 2030 р. Серед цілей, що визначені Стратегією, стратегічна мета 5 забезпечення переходу до моделей збалансованого споживання і виробництва, завдання для досягнення цієї цілі включають зокрема наступні заходи [5, с. 15-16]:

- до 2030 р. забезпечити системне інформування споживачів і виробників щодо значення та переваг збалансованого споживання та виробництва і формування сучасної культури споживання, зокрема ощадливого використання ресурсів;

- до 2030 р. впровадити національну стратегію освіти для сталого розвитку.

Одним з основних завдань реклами є стимулювання споживання, а отже вирішення завдання збалансованого споживання, що визначене Стратегією сталого розвитку України до 2030 р., створює суперечність.

Під впливом реклами людина втрачає можливість раціонального вільного вибору, бо її бажання програмуються ззовні. Необхідність захисту дітей від негативного впливу реклами, захисту споживачів i певних соціальних груп від впливу окремих рекламних образів, упередження деформацій моральних засад стає нагальною потребою для суспільства. Це зумовлює необхідність формування адекватної державної політики у сфері управління рекламною галуззю, активізації некомерційного громадського самоуправління, трансформації цільових складових у регулюванні рекламної діяльності, розширення взаємовідносин та взаємодії з громадськістю в системі державного управління.

Е. Фромм у своїй роботі "Мати чи бути?” дає дуже жорстку оцінку соціальної ролі реклами та її впливу на суспільство. Реклама з її суто сугестивними методами, на його думку, “переслідує людину скрізь, не даючи їй перепочинку ні вдень, ні вночі, занурюючи її в атмосферу напівзабуття та втрати відчуття реальності”. Він переконаний, що "необхідно заборонити в комерційній рекламі і політичній пропаганді будь-які методи “промивання мізків" [6, с. 413]. Питання ціннісних (архетипних) установок “мати” або “бути” в регулюванні реклами, з позицій соціальної концепції Е. Фромма, не повинно ставитися як вибір альтернативи. Може йтися про можливість досягнення оптимального співвідношення матеріальних інтересів бізнесу й нематеріальних цінностей суспільства в регулюванні рекламної сфери, зокрема за рахунок підвищення ефективності саморегулювання. Значення має співвідношення ціннісно-смислових архетипів “володіння” та “буття”. Найприйнятніша його форма - це творче володіння, коли суб'єкти рекламного самоврядування мають дієву мотивацію “буття”, яка доповнює, 
а не виключає корпоративні інтереси “володіння".

Ж. Бодрійяр, досліджуючи кризові явища в культурі XX ст., зазначив, що в суспільстві споживання завдання реклами зводиться до інтерпретації бажань. Бажання матеріалізуються в речах, а речі уособлюють бажання й матеріалізують певні функції суспільного устрою. Реклама створює світ, в якому суспільні проблеми вирішують не люди, а речі: “будь-яка напруга, будь-який індивідуальний чи колективний конфлікт можуть бути вирішені за допомогою певної речі" [7, с. 105].

У дослідженні Жиля Липовецькі відзначається, що постмодерністський стан європейської культури став результатом процесів, що заохочуються серед іншого масовим споживанням і засобами масової інформації [6, с. 44]. Сучасну епоху він називає “добою масового споживання” [8, с. 17].

У таких умовах, крім розвитку законодавства та зовнішнього контролю, вирішенню проблеми може сприяти ефективне самоврядування та саморегулювання в рекламній сфері. Саме саморегулювання може стати відповіддю на питання "мати чи бути”, точніше, поставити його в іншому ключі - “мати й бути”. Е. Фромм у своїй роботі вводить поняття “екзистенціальне володіння”, що визначається як раціонально обумовлене прагнення до самозбереження й не суперечить природі “буття” існування. Один із проявів цього принципу - творче володіння - може бути підставою ціннісної (архетипної) орієнтації саморегулювання, навіть не дивлячись на те, що в цілому під- приємницькій діяльності меншою мірою властивий архетип “буття”, проте, мотивація саморегулювання може лежати в цьому контексті в його обгрунтуванні. Практика саморегулювання показує, що воно здатне швидко, гнучко й без зайвих витрат забезпечити існування гармонійних відносин між рекламістами, суспільством і державою.

Як показує історичний досвід, трансформації в економіці і соціальній сфері відбуваються під впливом певних ціннісних установок (архетипів) учасників суспільно-владних відносин. Цілепокладання в регулюванні, що грунтується на ціннісних установках, сприяє збалансуванню інтересів учасників.

\section{Висновки і перспективи подаль-} ших досліджень. Концепція сталого розвитку в сучасній світовій соціально-економічній теорії та практиці розглядається як стратегія вирішення проблем збереження та відтворення навколишнього природного середовища і забезпечення високого рівня життя населення планети. Ceред завдань, що визначені у Стратегії сталого розвитку України до 2030 р. забезпечення збалансованого споживання та виробництва і формування сучасної культури споживання. У контексті цих завдань та з урахуванням масштабів рекламної індустрії, ï роль і можливості впливу на суспільство, слід розуміти, що навіть найдосконаліше законодавство й ефективна система зовнішнього контролю не зможуть усунути всі суперечності, пов’язані з нею. Але в умовах взаємодії із законодавчими механізмами, державними та громадськими системами зовнішнього контролю, 
рекламне саморегулювання здатне забезпечити існування гармонійних відносин між рекламістами, суспільством і державою.

Питання ціннісних установок в регулюванні реклами, з позицій завдань Стратегії сталого розвитку щодо збалансованого споживання, не повинно ставитися як вибір альтернативи. Може йтися про можливість досягнення оптимального співвідношення матеріальних інтересів бізнесу й нематеріальних цінностей суспільства у регулюванні рекламної сфери, зокрема у підвищенні ефективності саморегулювання. Значення має співвідношення ціннісно-смислових архетипів, що визначають творче володіння, коли суб'єкти рекламного самоврядування мають дієву мотивацію щодо соціальної відповідальності, яка доповнює, а не виключає корпоративні інтереси.

\section{СПИСОК ВИКОРИСТАНИХ ДЖЕРЕЛ}

1. Кораблин C. Великая депрессия. Украина [Электронный ресурс] / С. Кораблин // Зеркало недели. 2015. - № 30. - Режим доступа: https://zn.ua/macrolevel/velikayadepressiya-ukraina- .html

2. Serdechna L. V. Economic and legal aspects of development of the advertisement in Ukraine / L. Serdechna // The Strategic Potential of the State and Territorial Development [collective monograph] / European Institute of Continuing Education - Donetsk State University of Management: Slovak Republic, Podhájska, 2017. - P. 37-53.

3. Марк М. Герой и бунтарь. Создание бренда с помощью архетипа / М. Марк, К. Пирсон; пер. с англ. под ред. В. Домнина, А. Сухенко. СПб.: Питер, 2005. - 336 с.

4. ВООЗ. Проблема ожирения в Европейском регионе ВОЗ и стратегии ее решения / под ред.: Francesco Branca, Haik Nikogosian и Tim Lobstein. - Б/м : Всемирная организация здравоохранения, 2009. $392 \mathrm{c}$.

5. Стратегія сталого розвитку України до 2030 р. [Електронний ресурс] / Проект-2017, 108 с. - Режим доступу: http://www.ua.undp.org/content/ dam/ukraine/docs/SDGreports/ UNDP_Strategy_v06-optimized. pdf

6. Фромм Э. Забытый язык. Иметь или быть? / Э. Фромм ; пер. с нем. и англ. - М.: АСТ; АСТ-Москва, 2009. - $442 \mathrm{c}$

7. Бодрийяр Ж. Система вещей / Ж. Бодрийяр. - М. : Рудомино, 2001. - 216 c.

8. Липовецки Л. Ж. Эра пустоты: Эссе о современном индивидуализме / Л. Ж. Липовецки. - СПб. : Владимир Даль, 2001. - 336 с.

\section{REFERENCES}

1. Korablin $S$. Velyka depresiia. Ukraina [The Great Depression. Ukraine] available at: https://zn.ua/macrolevel/velikaya-depressiya-ukrainahtml (accessed March 30, 2019).

2. Serdechna L. V. (2017). Economic and legal aspects of development of the advertisement in Ukraine. The Strategic Potential of the State and Territorial Development [collective monograph], (p. 37-53). European Institute of Continuing Education - Donetsk State University of Management: Slovak Republic, Podhájska.

3. Margaret Mark and Carol S. Pearson, (2005). Geroy i buntar [The Hero and The Outlaw]. St. Petersburg: Peter [in Russian]. 
4. Francesco Branca, Haik Nikogosian and Tim Lobstein (Eds.). The challenge of obesity in the WHO European Region and the strategies for response. (2009), WHO.

5. Stratehiia staloho rozvytku Ukrainy do 2030 roku [The Strategy of Ukraine's Sustainable Development till 2030], available at: http://www.ua.undp.org/ content/dam/ukraine/docs/SDGreports/UNDP_Strategy_v06-optimized.pdf (accessed March 30, 2019).
6. Fromm E. (2009). Zabytyj yazyk. Imet' ili byt'? [Forgotten language. To have or to be?]. Moscow : AST [in Russian].

7. BaudrillardJ. (2001), Sistema veshchej [The system of objects]. Moscow : Rudomino [in Russian].

8. Lipovetsky G. (2001), Ehra pustoty: Ehsse o sovremennom individualizme [The era of emptiness: An essay on modern individualism], SPb. : Vladimir Dal' [in Russian]. 